\title{
MAP2K4 wt Allele
}

National Cancer Institute

\section{Source}

National Cancer Institute. MAP2K4 wt Allele. NCI Thesaurus. Code C97675.

Human MAP2K4 wild-type allele is located in the vicinity of 17p11.2 and is approximately $123 \mathrm{~kb}$ in length. This allele, which encodes dual specificity mitogen-activated protein kinase kinase 4 protein, plays a role in both protein phosphorylation and MAPK familydependent signal transduction. 